\title{
Community-driven renewal of industrial heritage and revitalization of old industrial area: A case study of Shimizusawa, Japan
}

\author{
Yixin ZHANG, School of Architecture, Tsinghua University, China \\ Jian LIU, School of Architecture, Tsinghua University, China \\ Dong SU, School of Architecture, Tsinghua University, China
}

\begin{abstract}
Old industrial areas are often stigmatized as areas that need to be abandoned or need to be rescued by top-down efforts. Their subjective initiative and the rejuvenation of industrial heritage are often overlooked. This concept is one-sided. The case of Japan's Shimizusawa region shows the active practice of a closed mining town actively using mining heritage to seek its own development. Its revitalization model can be summarized as the following principles: (1) Intrinsic development motivation driven by the community; (2) It was based on the industrial heritage of the community; (3) Community participation in the development process; (4) The community benefited from it. This model has enlightenment for other old mining areas whose population and economy have declined due to the closure of mines: only by fully respecting and giving full play to the subjectivity of industrial towns can it be possible to truly achieve local revitalization and sustainable development.
\end{abstract}

\section{Keywords}

Community, Resident, Coal mining, Tourism, Art, Memory

\section{Introduction}

\subsection{Literature}

Old industrial areas often face economic decline and population aging problems. Industrial heritage can be a catalyst for sustainable development. However, in the political and cultural discourse since modern times, the "old industrial area" is often regarded as the "other" of modernity, a passive place to be saved by top-down efforts, and its own subjectivity and industrial heritage is often ignored or underestimated. Although the 798 Art District in Beijing, China(Dai et al., 2015) and the Pier-2 Art Centre in Kaohsiung, Taiwan(Chan et al., 2019) have obvious bottom-up characteristics, most of the participants are outsiders rather than residents of the old industrial area, and cannot be used as a classic mechanism.

\subsection{Methodology}

This article uses field research and literature review method to introduce the historical evolution and heritage development of this area. 
Before starting the discussion, there are two concepts that need to be clarified. First, it is the meaning of "industrial heritage". The definition of industrial heritage in the Nizhny Tagil Charter is: industrial heritage is the remains of industrial civilization and has a variety of values. These remains include buildings, factories and other mines and warehouses, energy production, transportation and other places, as well as industrial-related housing, education and other social activities sites(TICCIH, 2003). In addition to this definition, this article also incorporates the definition of coal mine memory in the "Sorachi Charcoal Regional Activation Strategy" (the coal production of the coal mines and the city's features, people's work, life, cultural scenes, etc. in the Sorachi area, and records), as well as the definition of coal mine heritage (the tangible things in the "memory of coal mines"), together serving as the content of the industrial heritage of the Shimizuzawa community(Bureau, 2008). The Shimizusawa area is part of Yubari City, Sorachi.

Second, it is the meaning of "community". UNESCO defines "community" as people who directly or indirectly participate in the implementation and inheritance of a certain intangible cultural heritage project or a series of intangible cultural heritage projects, and recognizes that the intangible cultural heritage project is part of their cultural heritage. "Communities" vary in size and change with context. The community and the people who make up the community are the main body of the protection and inheritance of intangible cultural heritage projects(Yang, 2016). In this article, in addition to the people of Shimizuzawa, outsiders who live in Shimizuzawa and participate in the development of industrial heritage in the area are also regarded as part of the community, such as artists. The people that make up this community are diverse.

\section{From "a strong mining area" to a "hollow town": the changes in the Shimizusawa area}

The Shimizusawa area is part of Yubari City, Sorachi Comprehensive Promotion Bureau, Hokkaido, and is located at the confluence of the Yubari River and the Shihoro-Kabe River. The area is $3.3227 \mathrm{~km}^{2}$ and the population is 3191 . When entering the Shimizusawa area, the first thing you notice is usually the red and blue old coal mine houses, the green and blue mine forests, and the lakeside dam scenery. Its revitalization process and the key role that industrial heritage plays in it provide an excellent case for the discussion of this article.

In 1906, the Yubari Mine started mining, and mining gradually became a pillar industry. In order to ensure that the power supply throughout the series mines, Beitan company set up Power plant in 1926, and set up reservoirs of hydroelectric power in 1940. From the 1940s to the 1970s, the Beitan Tombor Mine, the Beitan Shimizusawa Mine, the Mitsubishi Nandai Yubari Mine, and the Beitan Yubari New Mine started one after another, and the urban area became more prosperous. However, all coal mines were closed in 1990, and the Oyubari Railway was also abolished. In 1991, the Shimizusawa Electric Power Station was also abolished, and coal-related functions disappeared(Sato, 2009).

After the coal mine was closed, many coal mine related facilities were demolished. However, some coal mine remains are relatively intact, such as Beitan Shimizusawa Power Plant, coal settlements and streets in the center of the city. Therefore, the Shimizusawa area is suitable for the development of Yubari City's future development of a tourist city that utilizes the regional cultural context and that is dominated by citizens. However, in the early days, local residents had insufficient awareness of the value of coal mine heritage in the area, and activities to utilize the heritage have not been carried out. Since then, with mining job losses and massive outflow of population, total population decreased significantly. In 2008, though Shimizusawa is the most populous region in Yubari, but the total population by the heyday 
of 13,000 people reduced to 2668 people. The aging rate reached $42.5 \%$ (2005 census), showing a serious aging trend(Sato, 2009).

\section{The origin of industrial heritage development}

The present dilemma has inspired the residents of Shimizusawa to survive and change, and promoted the driving force of the region to actively explore the road to revitalization. With both external and internal conditions, the Shimizusawa area has embarked on a path of "promoting local revitalization with industrial heritage".

\subsection{External conditions}

In 2008, the "Sorachi Charcoal Regional Activation Strategy ( 2008-2018)" (Bureau, 2008) was released, and the development of industrial heritage tourism was the core content, and Shimizusawa was chosen as an important point in this strategy (Figure 1).

In 2011, the "Yubari Shimizusawa Art Festival", one of the annual art festivals of Sorachi Coal Mine, was a milestone event in the history of the utilization of the industrial heritage of Shimizusawa and brought a turning point for local development. It has attracted many artists to visit, and it has also awakened the sleeping memory of residents.

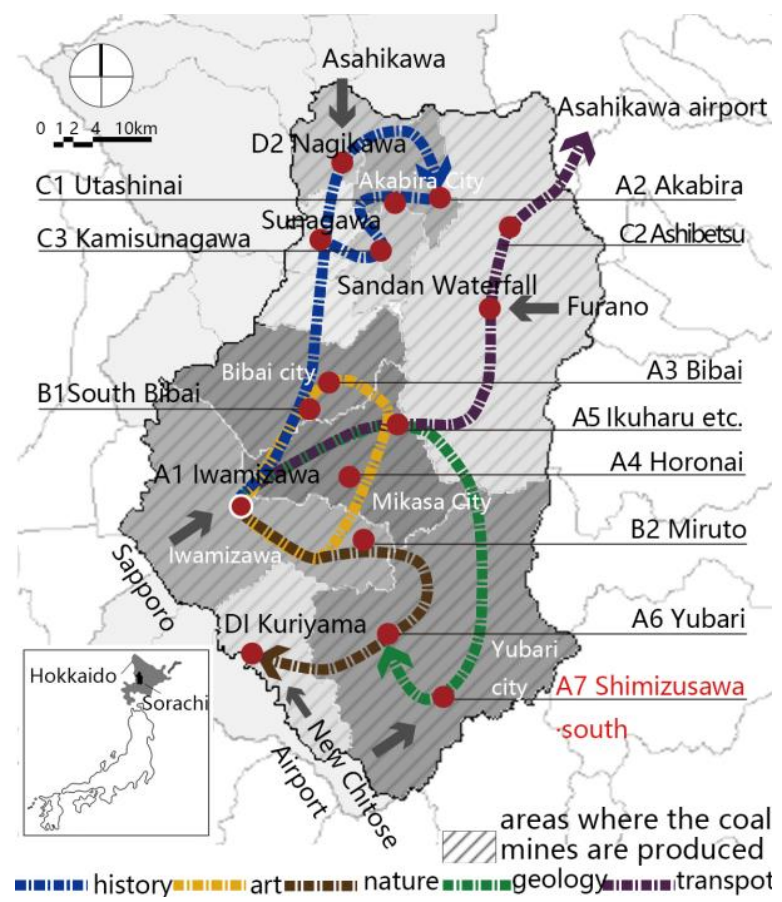

Figure 1. Industrial tourism routes in Sorachi Charcoal Regional Activation Strategy. Source: adapted from (Bureau, 2008).

\subsection{Internal conditions}

2009 Manami Sato's Master's Degree "A study of tourism based on the concept of ecomuseum utilizing coal mine heritage for regional revitalization in Yubari city", believes that "it is feasible to use heritage for urban development " and proposes the usage of "The conception of Shimizusawa Eco-Museum" to guide residents to explore local coal mine heritage and promote regional revitalization through heritage tourism(Sato, 2009). 
In May 2016, Sato presided over the establishment of the Shimizusawa project corporate legal person (transformed into a non-profit company NPO in 2017), as the responsible group of the Shimizusawa project, established the official website(Shimizusawa, 2016a), began operating the project. The "Concept of Shimizusawa Eco-Museum " was fully embodied and implemented in the Shimizusawa project.

The 2016 "Yubari City Regional Population Vision and Regional Comprehensive Strategy" included the key content of the "Shimizusawa Project as a heritage tourism node". In July of the same year, the Shimizuzawa project corporate legal person and the government signed a cooperation agreement for the Shimizuzawa project, marking that the community-driven heritage utilization has been supported by the government.

\section{Main methods of industrial heritage development}

\subsection{Revitalization plan: two ten-year plans of heritage utilization}

Shimizusawa has formulated two ten-year revitalization plans. The first plan was proposed in Sato's paper in 2008. It had a total of 10 years and 4 stages. Each stage set goals in terms of overall goals, operating entities, activity entities, activity frequency, and equipment maintenance. The basic starting point of the plan is to realize the revitalization of regional revitalization through the concept of ecomuseum, including regional coal mine memory regeneration (the foundation of the eco-museum, leaving memories of production and life for future generations, such as interviews, data collection, urban research, and coal mining technology preservation), style regeneration (using planning or media show past mining style, such as photo exhibition, relics preserved, gardening, scene reproduction, etc., and geographical landscape is therefore recalled), and resources reuse (utilization of coal resources, including for the purpose of modern refurbishment to reflect multi-dimensional values, such as building trails in mines, reusing empty houses, converting stations into community spaces, etc.)(Shimizusawa, 2016a)(Table 1).

The most critical point in the plan is the idea of the operating personnel: the early operation of the ecomuseum, including research functions, will be mainly promoted by the external NPO of Shimizusawa Sorachi NPO Coal Mine Memory Promotion Affair Group; along with the establishment of a good relationship between outsiders and residents, the ultimate goal will be jointly managed by residents and external "fans". The reason why Sato made the "resident participation" plan is because the survey results showed that although local residents were currently less independent, they had shown confidence in rebuilding the local area, and with more and more attention of outsiders, the willingness of using the heritage of local coal mines and resources for urban construction will become stronger and stronger. This key factor was realized in 2016, namely the establishment of the "Shimizusawa Project Legal Person".

Table 1. The first ten-year plan. Source: (Shimizusawa, 2016a).

\begin{tabular}{|c|c|c|c|c|}
\hline & $\begin{array}{l}\text { Phase } 1(2008 \\
\sim 2010)\end{array}$ & $\begin{array}{l}\text { Phase } 2 \\
(2011 \sim 2013)\end{array}$ & $\begin{array}{l}\text { Phase } 3 \\
(2014 \sim 2017)\end{array}$ & Ten years later (2008) \\
\hline Target & $\begin{array}{l}\text { By creating } \\
\text { new things to } \\
\text { get to know } \\
\text { people }\end{array}$ & $\begin{array}{l}\text { To understand the } \\
\text { meaning of each } \\
\text { "renewable" } \\
\text { (memory } \\
\text { regeneration, } \\
\text { landscape } \\
\text { regeneration, } \\
\text { resources } \\
\text { regeneration) }\end{array}$ & $\begin{array}{l}\text { In each topic } \\
\text { "renewable" } \\
\text { activities }\end{array}$ & $\begin{array}{l}\text { Achieve economic and cultural } \\
\text { revival }\end{array}$ \\
\hline
\end{tabular}




\begin{tabular}{|c|c|c|c|c|}
\hline $\begin{array}{l}\text { Operation } \\
\text { personnel }\end{array}$ & $\begin{array}{l}\text { Non-profit } \\
\text { organizations } \\
\text { and local } \\
\text { residents }\end{array}$ & $\begin{array}{l}\text { The nonprofit } \\
\text { organization and } \\
\text { people from region } \\
\text { and beyond region }\end{array}$ & $\begin{array}{l}\text { Operating } \\
\text { organization } \\
\text { composed of } \\
\text { residents and } \\
\text { the external } \\
\text { personnel } \\
\text { will emerge }\end{array}$ & $\begin{array}{l}\text { Operating organization (NPO or } \\
\text { company organization pursuing } \\
\text { of the lowest profit) may be } \\
\text { equipped with a full-time staff }\end{array}$ \\
\hline $\begin{array}{l}\text { Activity } \\
\text { personnel }\end{array}$ & $\begin{array}{l}\text { Outsiders } \\
\text { (such as } \\
\text { expert) as the } \\
\text { main } \\
\text { personnel }\end{array}$ & $\begin{array}{l}\text { some residents and } \\
\text { visitors }\end{array}$ & $\begin{array}{l}\text { A large } \\
\text { number of } \\
\text { residents and } \\
\text { visitors }\end{array}$ & $\begin{array}{l}\text { Residents participate daily } \\
\text { activities, which will attract } \\
\text { heritage lovers continuously }\end{array}$ \\
\hline $\begin{array}{l}\text { Activity } \\
\text { frequency }\end{array}$ & $\begin{array}{l}\text { Held once in a } \\
\text { while }\end{array}$ & $\begin{array}{l}\text { Gradually develop } \\
\text { activities from the } \\
\text { bottom up }\end{array}$ & $\begin{array}{l}\text { Become } \\
\text { active, } \\
\text { conduct } \\
\text { surprise to } \\
\text { visitors to } \\
\text { participate in } \\
\text { the daily } \\
\text { activities }\end{array}$ & Often hold \\
\hline $\begin{array}{l}\text { Equipment } \\
\text { maintenance }\end{array}$ & $\begin{array}{l}\text { The } \\
\text { independent } \\
\text { maintenance } \\
\text { of each type } \\
\text { of resource }\end{array}$ & $\begin{array}{l}\text { maintenance } \\
\text { according to theme } \\
\text { and center } \\
\text { maintenance }\end{array}$ & $\begin{array}{l}\text { Different } \\
\text { themes } \\
\text { linkage }\end{array}$ & $\begin{array}{l}\text { In cooperation with other } \\
\text { regions }\end{array}$ \\
\hline
\end{tabular}

The second plan was initiated by the Shimizuzawa project legal person in 2019, and it is still 10 years and 4 stages, including the objectives of facility population, operation entities, activity entities, resource preparation, and the number of members(Shimizusawa, 2016a). On the basis of the first plan, there are two promoted points: the first is the close integration of heritage use with urban construction; the second is more attention paid to organization of activities, such as cooperating with public and education departments to encourage senior citizens to participate in heritage activities (Table 2). It can be found that the cooperation and joining of the government in 2016 is an important reason for the smooth development and expansion of the Shimizuzawa project.

The two ten-year plans have made the revitalization vision clearer, and the use of the heritage has been steadily promoted, resulting in a higher degree of completion: the heritage and landscape have been effectively protected; the corporate legal person of the Shimizusawa project was transformed into a nonprofit company NPO in 2017 ; as of 2021 , the number of members has reached more than 40 and so on. Another function of the plan is to enable residents and other people committed to local development to understand the direction of action, which is conducive to multi-party cooperation.

Table 2. The second ten-year plan. Source: (Shimizusawa, 2016a).

\begin{tabular}{|c|c|c|c|c|}
\hline & Phase 1 (2019 2021) & $\begin{array}{l}\text { Phase } 2(2022 \\
\sim 2024)\end{array}$ & Phase 3 (2025 2028) & Ten years later (2029) \\
\hline $\begin{array}{l}\text { Faciliti } \\
\text { es and } \\
\text { aims }\end{array}$ & $\begin{array}{l}\text { Compound facilities and } \\
\text { early childhood education } \\
\text { center }\end{array}$ & $\begin{array}{l}\text { Shimizusawa } \\
\text { water } \\
\text { hydroelectric } \\
\text { power plant }\end{array}$ & $\begin{array}{l}\text { Get rid of funding } \\
\text { support }\end{array}$ & $\begin{array}{l}\text { The population of } \\
4603 \text { people }\end{array}$ \\
\hline $\begin{array}{l}\text { Opera } \\
\text { ting }\end{array}$ & Provide employment & $\begin{array}{l}\text { Ensure the } \\
\text { income }\end{array}$ & $\begin{array}{l}\text { Form a sustainable } \\
\text { management system; }\end{array}$ & $\begin{array}{l}\text { Come up proposals } \\
\text { that can be adopted }\end{array}$ \\
\hline & 100 & \multicolumn{3}{|c|}{$\begin{array}{l}\text { 57 }^{\text {th }} \text { ISOCARP World Planning Congress } \\
8-11 \text { November } 2021 \text { | Doha, Qatar }\end{array}$} \\
\hline
\end{tabular}




\begin{tabular}{|c|c|c|c|c|}
\hline $\begin{array}{l}\text { perso } \\
\text { nnel }\end{array}$ & & & $\begin{array}{l}\text { Establish the board of } \\
\text { directors }\end{array}$ & $\begin{array}{l}\text { and integrated in } \\
\text { urban plan }\end{array}$ \\
\hline $\begin{array}{l}\text { Activit } \\
\text { y } \\
\text { perso } \\
\text { nnel } \\
\text { Resou }\end{array}$ & $\begin{array}{l}\text { Active participation of the } \\
\text { elderly; Cooperating with the } \\
\text { department of public and } \\
\text { education }\end{array}$ & $\begin{array}{l}\text { Cooperate } \\
\text { with various } \\
\text { external } \\
\text { stakeholders }\end{array}$ & Strengthen the activity & $\begin{array}{l}\text { As an organization } \\
\text { supporting a various } \\
\text { kinds of community } \\
\text { activities }\end{array}$ \\
\hline $\begin{array}{l}\text { rce } \\
\text { prepar } \\
\text { ation } \\
\text { Memb }\end{array}$ & Protect urgent heritage & $\begin{array}{l}\text { Build digital } \\
\text { archive }\end{array}$ & $\begin{array}{l}\text { Carry out the fund } \\
\text { plan }\end{array}$ & $\begin{array}{l}\text { Protect important } \\
\text { heritage, landscape }\end{array}$ \\
\hline $\begin{array}{l}\text { numb } \\
\text { er }\end{array}$ & 50 & 80 & 120 & \\
\hline
\end{tabular}

\subsection{Material space: two spatial plans of ecomuseum}

Corresponding to the two plans, Shimizusawa's two physical space plans adopted the concept of "ecomuseum". "Shimizusawa Eco-Museum" is a field museum that can reflect local culture and characteristics with the functions of "collection", "preservation", "exhibition" and "education.research" defined by the museum(Shimizusawa, 2016a). It will turn the entire town into a museum. The concept of the ecomuseum spread from France to Japan. In the 1980s, the museologist Shigezo Arai made localized improvements to establish a unique interpretation system and a "core - satellite facility" model. Based on this, Japan Ministry of Agriculture, Forestry and Fisheries established the "Pastoral Space Museum" system in 1998. Both goals are to promote local revitalization with heritage, which is already a relatively mature methodology in Japan. The "eco-museum concept" includes the three elements of "core museum-satellite museum-exploration path"(Shi, 2019). "Core museum" refers to a building that is transformed from a landmark coal mine heritage and serves as a civic activity and visitor center; "satellite museum" refers to other tourist attractions covering a certain space, such as geological relics, outcropping charcoal sites, mining parks and other natural sites. Heritage, coal mine blocks, production facilities and other cultural heritage; "exploration paths" may be trails and bicycle paths that connect museums, or a linear and independent satellite museum, such as a railway tourist driving line.

The first space planning plan comes from the "Eco-Museum Conception" in Sato's master's thesis. The plan was centered on three themes: coal mines, urban center, and coal mine residences. The "coal mine" theme exhibited the relics related to coal production, such as electricity and hydraulic facilities; the "city center" theme displays the old stations and railways, because this place was an important coal transportation hub in Yubari City in the 1980s; "the "coal mine residences" theme" showed the diversity of coal mine residences and coal mine residential communities, such as the old daily life scenes composed of flower beds, vegetable gardens and other elements. Each theme center was not only an exhibition explaining the theme, but also an activity base for local residents (in the theme of "city center" and "coal house", satellites were widely used, and there were no specially planned walking paths). The core museum was planned to be located near the former Shimizusawa Post Office. It provided explanations of local coal mine memories, as well as research, publicity, information, education, and service activities(Sato, 2009)(Figure 2).

The purpose of this conception is to transform "scenic heritage tourism" into "residential heritage tourism", and change the phenomenon that non-attractive coal mine residences and other areas have less tourists in the past. For example, in coal mine residential areas, tourists can establish friendly 
relations with residents, recognizing that the locals themselves are unique scenery. The core museum suplies a one-stop service, providing a window for internal and external exchanges.

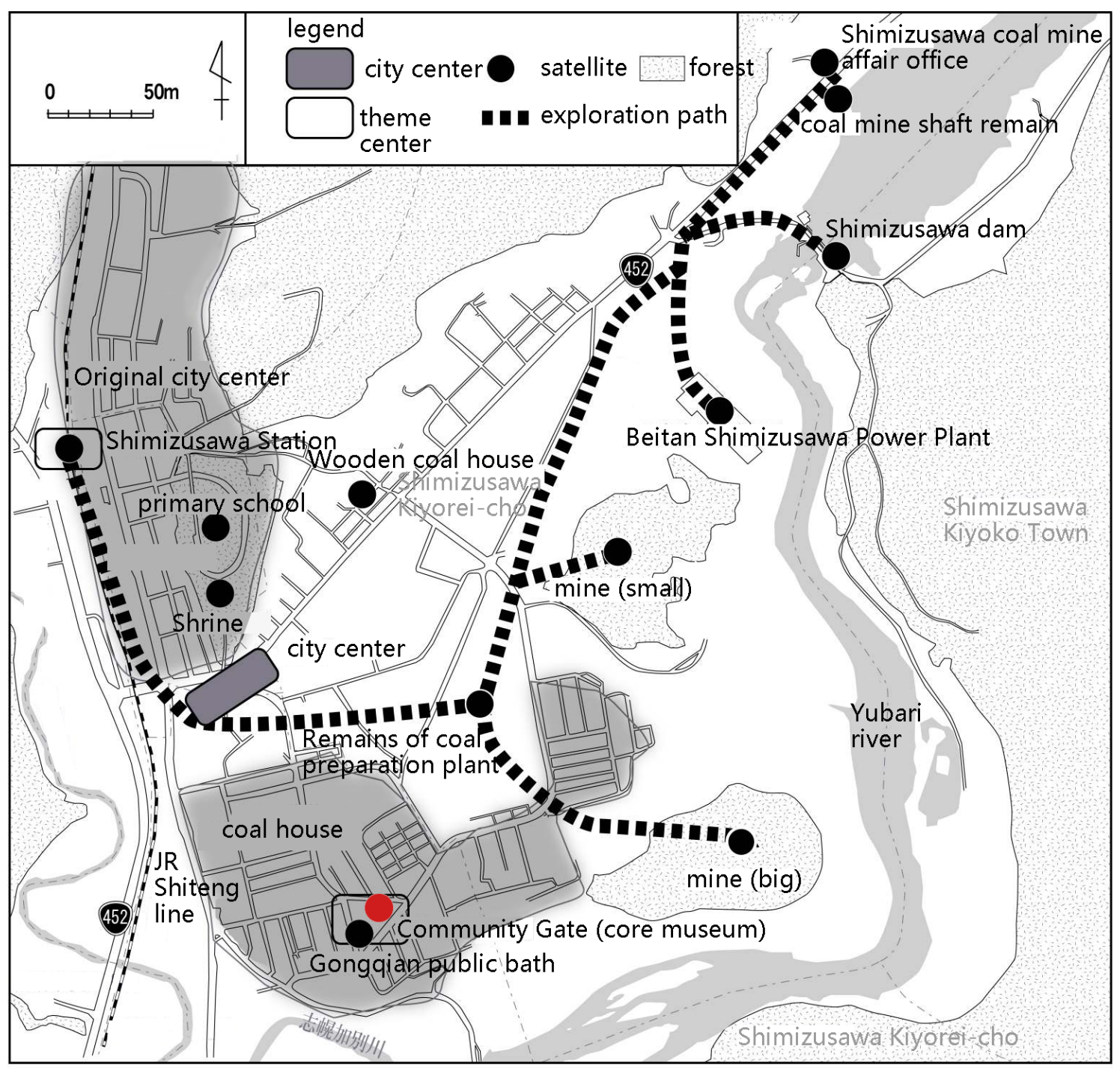

Figure 2. The first space planning plan based on the "Eco-Museum Conception". Source: reference (Sato, 2009).

On the basis of the first spatial plan, the second plan had the following innovations: (1) It reclassified the mining heritage according to the three themes of "electricity, iron, and carbon", and deepened the use of various themes, such as mines annual maintenance. (2) The old coal mine residence "Gong 23 " would be transformed into a complex activity center, named "Gate of Shimizusawa Community", as the new core museum. It assumed the functions of a visitor center and immigration space externally, and organizes various civic activities internally, which provided convenience for internal and external exchanges. (3) The purpose of Shimizusawa Eco-Museum was redefined to use the heritage of the local coal mines to encourage people inside and outside the area to establish mutual respect and make Shimizusawa a proud area(Sato, 2009)(Figure 3).

In addition to the basic preservation and reuse of the heritage, this stage encourages residents to participate, and guides each citizen to recognize the knowledge, technology, and experience he has cultivated in the local area, actively think about the future of the region, and create opportunities for 
development. For example, cooperation with educational and research institutions, cooperation with the Sapporo International Art Festival, calling on residents to participate in actions that concretize the idea of urban construction, training tour guides and narrators, and inviting returning youth with higher education to participate in projects.

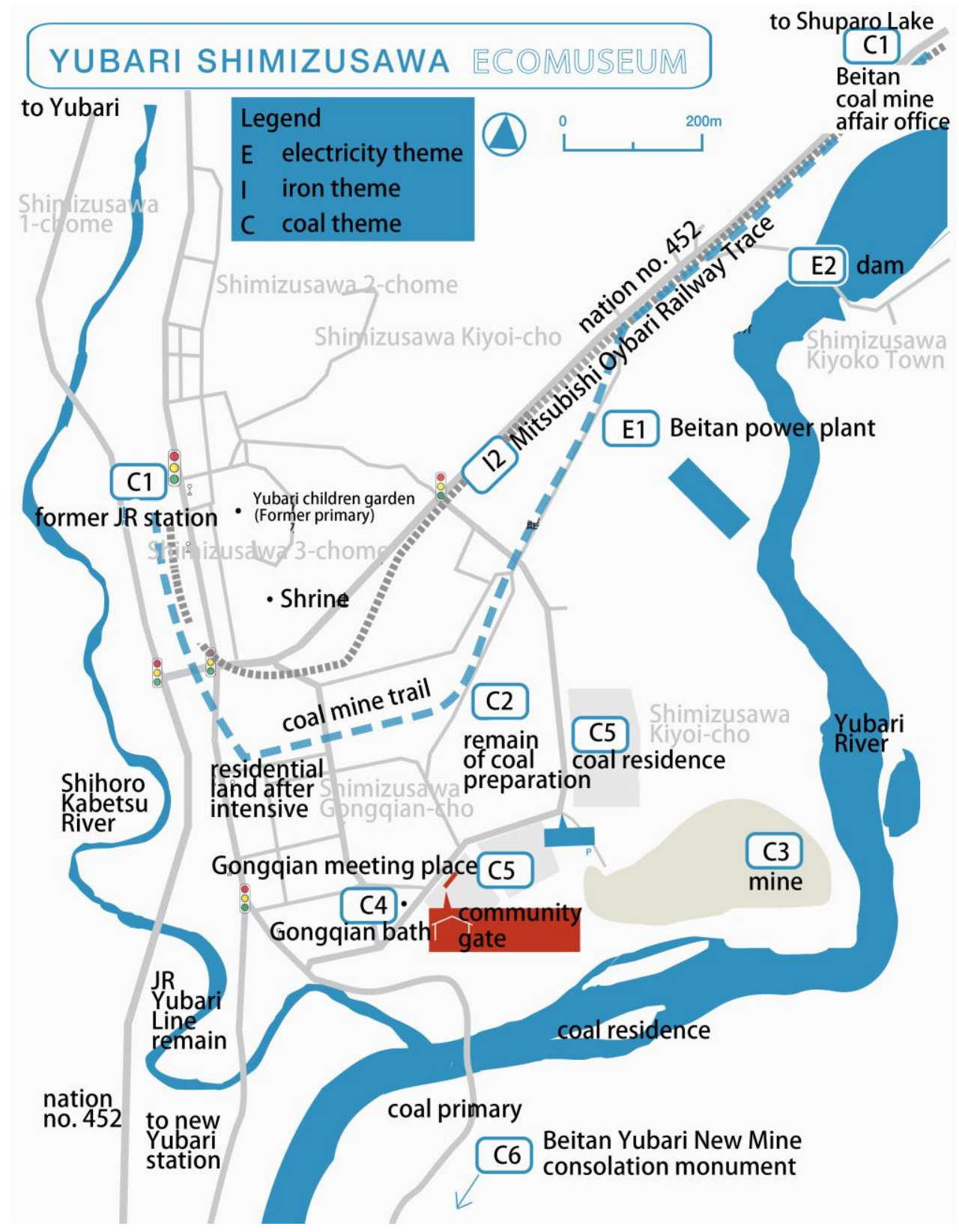

Figure 3. The second space planning plan based on the "Eco-Museum Conception". Source: reference (Shimizusawa, 2016a).

\subsection{Economic aspect: the development of new industries}

First, the tourism industry is developed. Since 2008 year "Sorachi Charcoal Regional Activation Strategy (2008-2018)" and 2016 Year "Yubari regional population and regional comprehensive strategic vision" were introduced, the coal mining heritage tourism industry has been considerable development in 
Shimizusawa. The eco-museum plan made the area a "walking" tourist town. Tourists can choose tourism themes, satellites and routes according to their preferences. For example, the "charcoal" theme includes the original Beitan Shimizusawa Coal Mine Office, the remains of the coal processing plant, and the Beitan Shimizusawa Mine, Miyama-cho Baths, Coal Mine Residential Street, Beitan Yubari New Mine Memorial Monument. The tour guide is served by NPO members or local residents, and some heritage sites need to be paid to visit. Beitan Shimizusawa Mine was transformed from a slag dump, with a height difference of about $60 \mathrm{~m}$ and a climbing trip of about 10 minutes. The top of the mountain provides a panoramic view of the city center of Yubari, which is popular with tourists and locals.

Second, the leasing industry is being developed. "The gate of the community" is a representative example of the lease and reuse of industrial heritage. It is located in the center of the Shimizuzawa area and was transformed from a four-unit row coal mine residence. It was built by Beitan Company in 1972 and changed to public housing after the mine closed. In 2016, the NPO Shimizusawa Association leased this house from the government as a heritage activity center for free. Since then, some rooms have been gradually transformed into shared spaces for commercial operations. Each unit type is 2LDK, and the total construction area of the upper and lower floors is $49.7 \mathrm{~m} 2$. A total of three units have been transformed into shared spaces, namely migration, office, and art spaces (Figure 4). Anyone who needs to use it can apply for a fee, and it can be used for 1 to 90 days(Shimizusawa, 2016b).
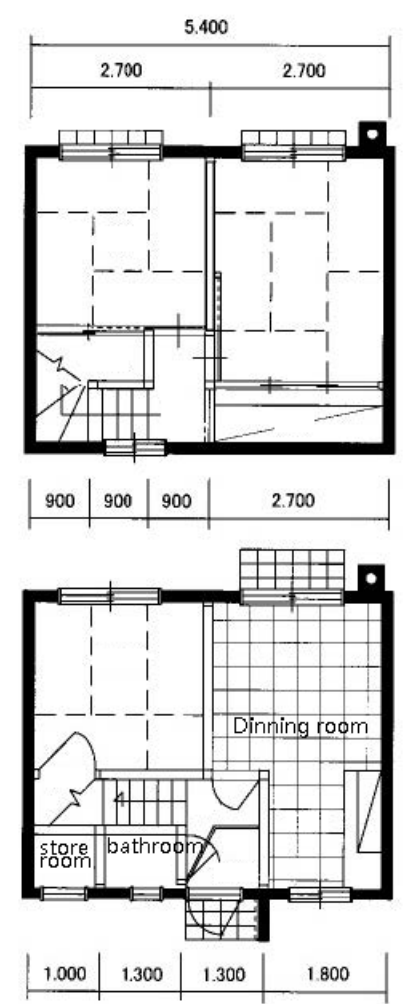
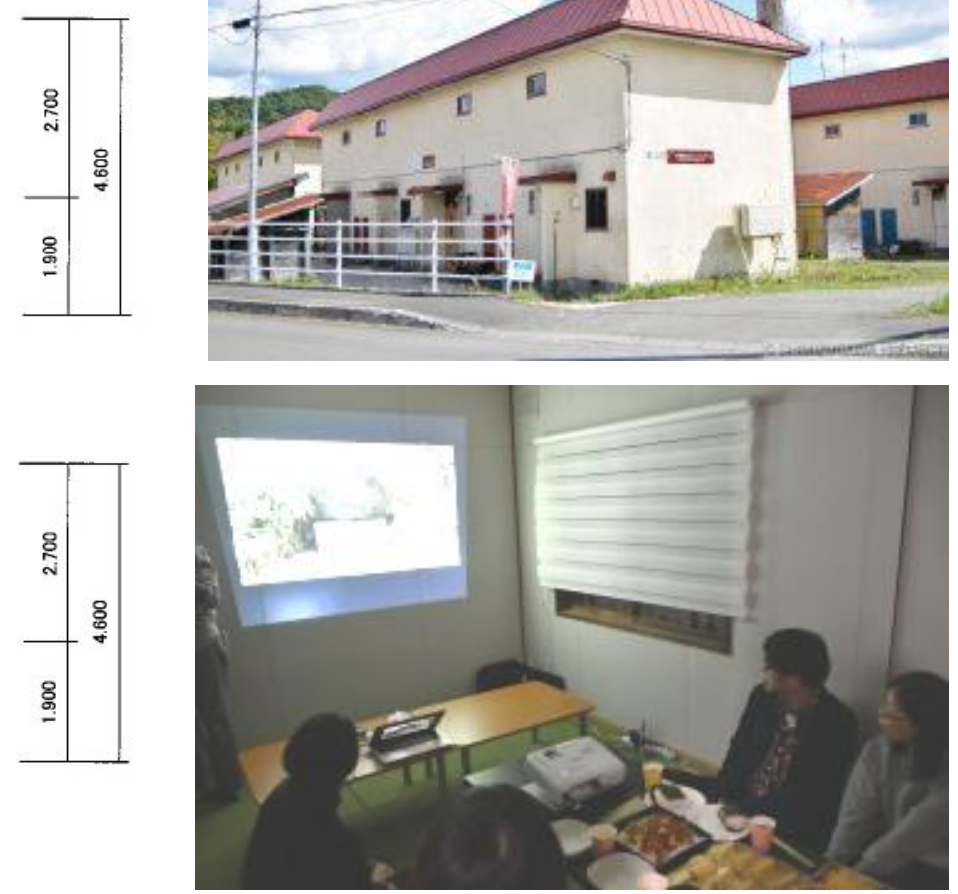

Figure 4. Floor plans, house exterior and internal decoration of the gate of the community. Source: reference (Shimizusawa, 2016b).

Once again, creative industries are being developed. It is mainly reflected in the use of industrial heritage as a venue for artistic events, such as annual art festivals, artist summer projects, and artist personal exhibitions. Take the annual art festival as an example. The venue is the original Beitan Shimizusawa Power Plant. During this festival, artists (experts, teachers and students) use various artistic thoughts and 
formal languages, use plants such as moss, metal, rubber sheets and other materials to decorate the power plant, visualize the "memory of coal mine", and create a sense of place. At the 2011 Annual Art Festival, participating artists' work "white feather", decorated the space with a variety of feathers like souls, making visitors recall coal memories of pioneers. It also exhibited many old photos(Shimizusawa, 2011a)(Figure 5). These artistic events are already an important source of income for Shimizuzawa.

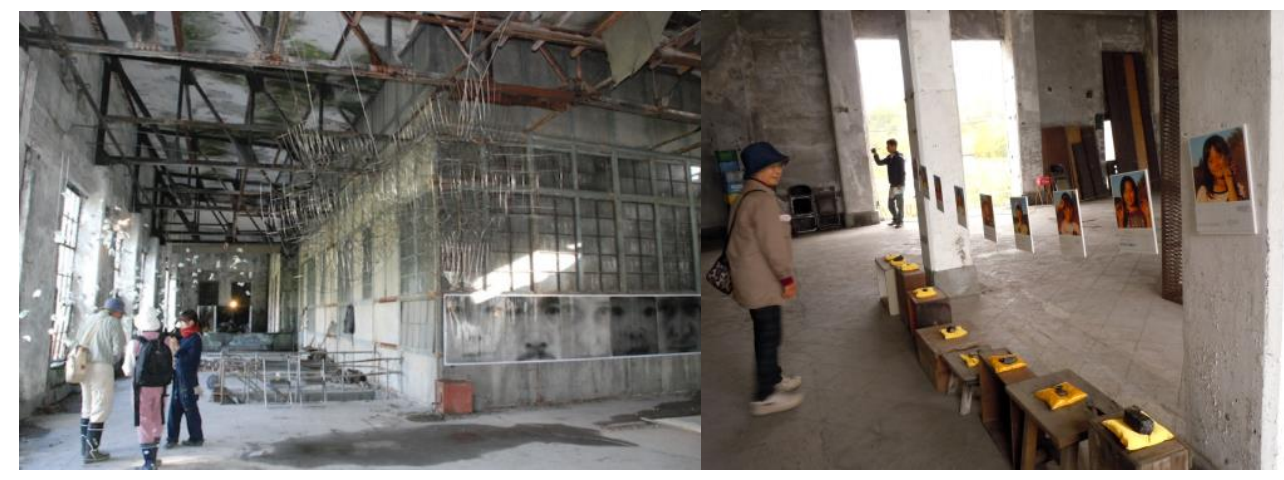

Figure 5. The annual art festival hold in the venue of original Beitan Shimizusawa power plant. Source: reference (Shimizusawa, 2011a).

\subsection{Cultural aspect: excavation, cultivation and inheritance of memory}

Cultural activities at the community level are conducive to the awakening of collective memory and the cultivation of cohesion among residents, and are very important to regional revitalization. The legal person of the Shimizusawa Project organizes various cultural heritage activities in terms of memory excavation, cultivation and inheritance.

The most representative "excavation" activity may be the "Shimizusawa Elementary School Memory Exhibition Collective Memory Collection Activity" in 2018. This activity collected the memories, information and old photos of residents who have studied in this coal mine elementary school and displayed them in the exhibition room(Shimizusawa, 2011b).

"Nurturing" activities are rooted in industrial heritage and regional characteristics. In order to cultivate people's love and confidence in their hometown, some activities of "making local characteristics into crafts" were organized, such as the "Yubari Textile Project", where residents were taught to dye old coal mine houses in "red and blue" on fabrics and they were given to the residents as souvenirs(Shimizusawa, 2020a)(Figure 6).

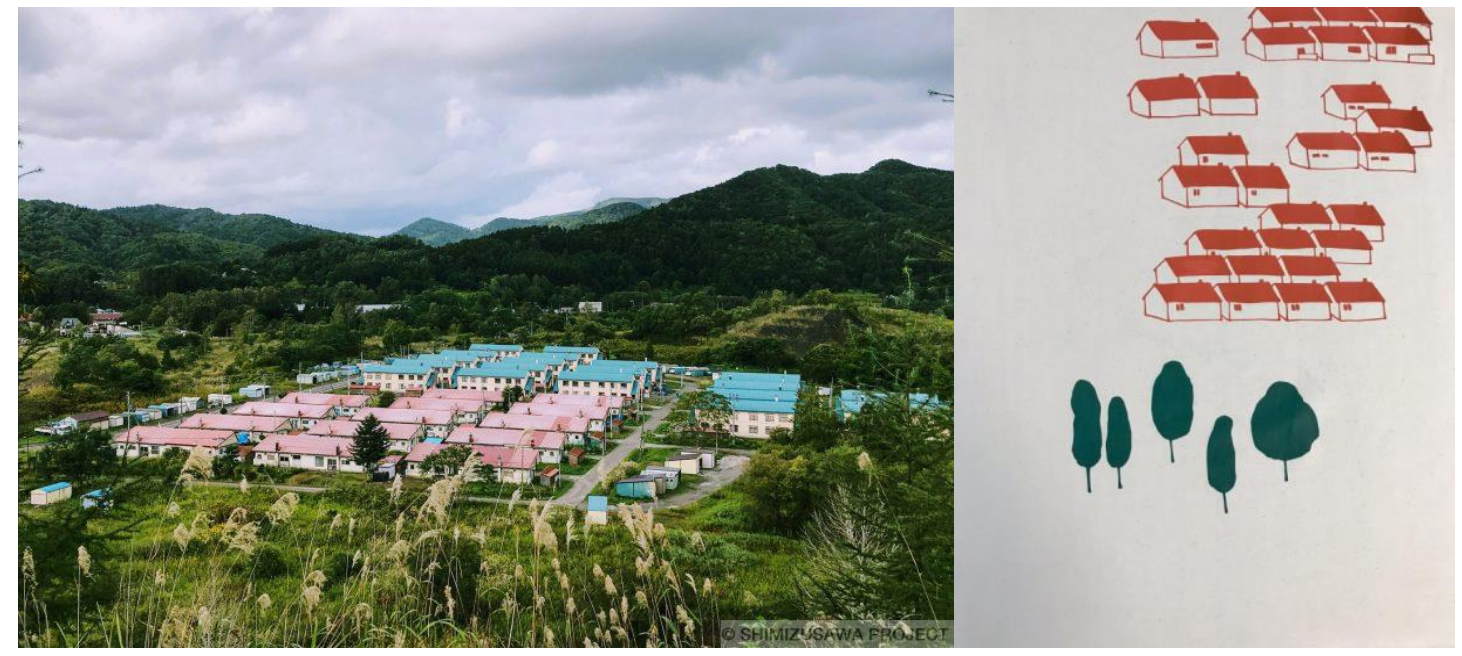

Figure 6. Dyeing old coal mine houses in "red and blue" on fabrics. Source: (Shimizusawa, 2020a). 
"Inheritance" activities are heritage activities for the future generation, with the main purpose of inheriting the coal mine culture and spirit. In addition to knowledge transfer and study tours, Shimizuzawa pays attention to using real objects as a medium to convey the memories of coal mines. Take the "Harunire Project" as an example. Under the premise of government authorization and enterprise cooperation, the trees of the original Shimizusawa Elementary School were made into highquality children's teeth rings and distributed to local babies; at the same time, some trees are being made to be wood slide which will be given to Early Childhood Education and Care Center (Figure 7), namely Yubari Hilltop Children Garden, in order to make memory borne in mind(Shimizusawa, 2020b).

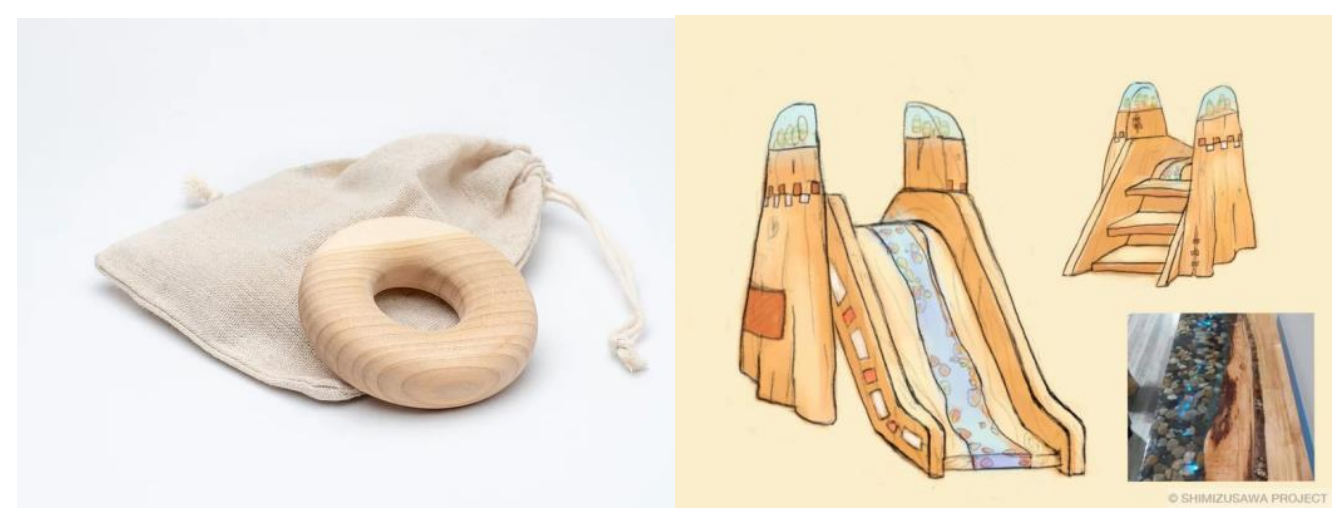

Figure 7. Teeth rings and wood slide in Harunire Project. Source: (Shimizusawa, 2020b).

\section{The key personnel of industrial heritage development}

\subsection{Community power}

It can be said that the NPO of the Shimizusawa Project has been playing a leading role in the entire process of industrial heritage and regional revitalization. It has formulated two ten-year plans and two physical space plans under the concept of eco-museum, organized new industrial space design and cultural activities, has clear corporate missions and undertaking business instructions, and gradually explored a sustainable management model. They have also built a bridge of communication between the government and residents.

Residents and artists are equally important. They are the inheritors and practitioners of industrial heritage and industrial culture, and they are the basic force that promotes the development of industrial heritage and local revitalization. For example, the renovation of the Shimizusawa Mine, such as mowing the grass, maintaining the stairs and benches, are done by local residents; the artist is good at presenting coal mine memories in a tangible way, which is conducive to the transmission of coal mine culture and emotions(Chung and Lee, 2019).

Equally important is the unprecedented neighborhood committee. The neighborhood committee provided support in various aspects. For example, in 2015, it opened the "Shimizusawa Community Gate" in cooperation with the Shimizusawa project legal person, and promoted its transformation into a multifunctional exchange base.

\subsection{Other powers}

The government and enterprises have also played an important role, especially without government joining and its permission, some heritages could not have been used. Therefore, it can be concluded that under the leadership of the NPO, the legal person of the Shimizusawa Project, various forces have worked together to finally promote the revitalization of the region. 


\section{Research results and outcomes}

Shimizusawa's revitalization process provides an excellent case for the community-driven model, and its success proves the effectiveness of this model: (1) Shimizusawa's motivation to implement industrial heritage renewal and regional revitalization came from solving the survival dilemma within the community. (2) The heritage resources it relies on mainly come from tangible coal mine heritage and intangible coal mine culture (memory), which are closely linked to urban construction through material planning, and further through economic and cultural innovation strategies, making it play a revitalizing role; (3) A broad community composed of NPO organizations, neighborhood committees, ordinary residents, and artists have jointly participated and worked together to complete the process of development and revitalization; (4) Finally, region developed, starting from "hollow towns" to a wellknown "industrial characteristic town", and villagers have benefited from the results of industrial heritage development and regional revitalization.

This "community-driven industrial heritage development and regional revitalization" model is an amendment to the popular local concept of closed mining industrial areas as passively waiting to be rescued, and has positive implications for the current implementation of the old industrial area revitalization strategy: only through showing sufficient respect and giving full play to the subjectivity and initiative of industrial towns, can the revitalization and sustainable development of old industrial areas be truly realized.

Future research can study how the special plan for industrial heritage renewal can be better integrated into the overall urban planning with community participation, and can also expand the economic and cultural development strategies of industrial heritage created or supported by residents, in order to provide multiple ways to revitalize the old industrial area.

\section{References}

Bureau, S. C. P. (2008). Sorachi Charcoal Regional Activation Strategy.

Chan, H. H., Hu, T. \& Fan, P. (2019), 'Social sustainability of urban regeneration led by industrial land redevelopment in Taiwan', European Planning Studies, 27(7), p1245-1269.

Chung, H. \& Lee, J. (2019), 'Community Cultural Resources as Sustainable Development Enablers: A Case Study on Bukjeong Village in Korea compared with Naoshima Island in Japan', Sustainability, 11(5), p1401.

Dai, J., Huang, X. \& Zhu, H. (2015), 'Interpretation of 798: Changes in Power of Representation and Sustainability of Industrial Landscape', Sustainability, 7(5), p5282-5303.

Sato, M. (2009). A study of tourism based on the concept of ecomuseum utilizing coal mine heritage for regional revitalization in Yubari city, Sapporo, Sapporo International University.

Shi, D. (2019), 'From ecomuseum to pastoral space museum: Janpanese rural rivatalization and practice', Chinese Museum, (1), p43-49.

Shimizusawa, G. I. A.(2011a), Former Beitan Shimizusawa Thermal Power Station. [online]. Available at: https://www.shimizusawa.com/hatsuden (Accessed: 06 April 2020)

Shimizusawa, G. I. A.(2011b), Shimizusawa Station Exhibition. [online]. Available at: https://www.shimizusawa.com/station (Accessed: 07 July 2021)

Shimizusawa, G. I. A.(2016a), A project to work on town development utilizing coal mine heritage in the Shimizusawa district of Yubari city. [online]. Available at: https://www.shimizusawa.com/shimizusawaecomuseum (Accessed: 02 March 2020)

Shimizusawa, G. I. A.(2016b), Shimizusawa community gate. [online]. Available at: https://www.shimizusawa.com/shimizusawacommunitygate (Accessed: 20 March 2020)

Shimizusawa, G. I. A.(2020a), Yubari roof pattern silk screen winding. [online]. Available at: https://www.shimizusawa.com/news/10003.html (Accessed: 27 August 2021) 
Shimizusawa, G. I. A.(2020b), Harunire project. [online]. Available at: https://www.shimizusawa.com/harunire (Accessed: 30 August 2021)

TICCIH (2003). The Nizhny Tagil Charter for the Industrial Heritage.

Yang, L. (2016), 'Putting the Communities in the Center Status and Definition of 'community' in UNESCO's Policies of Safeguarding ICH', Northwestern Journal of Ethnology, 91(4), p63-73+114. 